\title{
Strengthening the innovation of University Library and improving the core competitiveness
}

\author{
Ling Wang \\ Library Acquisition and Cataloging Department, Kunming University of Science and Technology. \\ Kunming China.
}

Keywords: University Library; management innovation; user demand; characteristic service; core competence.

\begin{abstract}
With the modern society's demand for information, the library service model has been unable to meet the needs of users. In order to help readers access to personalize and characteristic of the literature resources, the library must integrate the collection and network resources effectively, providing deep and personalized thematic services to meet the needs of the readers. At the same time, it is a new way to realize the sustainable development of Library.
\end{abstract}

\section{Introduction}

The document No. 3 "Regulations of the Libraries of Ordinary Colleges and Universities (Revised Edition)" was issued by the Department of Higher Education, Ministry of Education of P. R. China in 2002. In the Article one of Chapter one General Provisions, it has pointed out that "The university library is the document information center of the school, an academic institution serving the teaching and scientific research, and an important base for school informationization and social informatization. The work of the university library is an important part of the school teaching and scientific research work. The construction and development of the library in the colleges and universities should be compatible with the construction and development of the school. The level of the library is an important symbol of the overall level of the school." The university library has a dual role in the higher education system. First of all, the university library is a service organization of service teaching, scientific research, management and discipline construction, that is, university library serves academic activities; Secondly, the university library itself is an academic institution engaged in the construction, development, utilization and other related scientific research academic institutions, that is, the university library work itself is an academic activity. The dual identity of the university library determines that the university library plays an important role in the construction and development of the university, even the whole higher education. Throughout all universities at home and abroad, whether the university's geographical location, architectural style, facilities and equipment, or its decoration characteristics, the development direction, are all closely linked to each other, which is a good interpretation of the school's philosophy and cultural taste. Whether it is hardware or software services, has become an important symbol of the University.

\section{Management and Innovation of University Library}

1.1 The management of university library is to optimize the allocation of various resources of the library system through planning, organization, leadership and control methods, hoping to complete the mission of the library for teaching and scientific research work, and also providing the librarian, the service provider, a high degree of pride and a sense of accomplishment.

1.2 The innovation of university library refers to the process of using the new ideas, new technologies and new methods to re-integrate the existing resources, so as to promote the continuous improvement of the comprehensive benefits of the management system. The use of advanced, scientific management methods to innovate the management of university libraries, can better reflect the function of the modern university library to serve the scientific research teaching. 


\section{The Concrete Connotation of the Management Idea of University Library}

\subsection{The Needs of University Library Status}

The standards of university libraries provided by the association of American universities and Research Libraries are as follows: First, it is necessary to provide users with information and guidance services through various forms of information consultation and user education service activities; second, as the University's academic, teaching institutions, it should enable students to learn something in school, to provide services for the community after leaving school; third, librarians should cooperate with teachers to participate in curriculum construction, information literacy education, subject teaching assessment and other activities; forth, the teaching of the library can be personalized, to provide users with face-to-face consulting services, and to provide teaching and research staff with in-depth research and consulting services; at the same time, librarians should use the electronic or printed form of teaching materials to provide users with library education services in the traditional or high-tech way.

\subsection{The Needs for Information Services}

The contemporary society is characterized by knowledge and information, with the development characteristics as taking the economy as the driving force, taking modern technology as the support and taking modern management as the means to meet the needs of the people. With the continuous progress and development of human society, people's needs are constantly improving. Especially in today's society, with the development of digital, information and network, the demand for information service is becoming higher and higher.

\subsection{The Needs for Teaching and Scientific Research}

Teaching and research work is the eternal theme of university library work. As the information center of the library, the library is an important part of teaching and scientific research, and its work should focus on teaching and research. With the increase of college students' enrollment and professional categories, combined with the requirements of teachers and researchers in colleges and universities, the utilization rate of libraries is getting higher and higher, and the importance of university libraries is becoming more and more important. This requires that the library should take the initiative to get in touch with the faculty, research and department, keep abreast of the teaching and research activities of teaching and research personnel, and provide services for teaching and scientific research personnel in a new management concept through a variety of ways, so as to make the the university library become the staff and information center of teaching and scientific research work, and play its due role in teaching and scientific research.

\section{Innovation of the Concept of Running A Library}

The rapid development of information technology has brought new challenges to the library work. The new changes require us to have a constant innovation in the concept of library management. In order to realize the sustainable development of the university library, it is necessary to establish the people-oriented management concept. The innovation of the concept of running a library refers to the concept innovation, system innovation, management innovation, technological innovation and service innovation.

\subsection{Concept Innovation}

As a non - profit organization, the university library must carry out the ideological and innovative ideas to improve the reader satisfaction as a university library work orientation. Reader satisfaction is the starting point and destination of university library management innovation. In the era of knowledge economy, the demand for knowledge information of university library readers will enter a stage of diversification, individuation and high efficiency. The university library must firmly establish the concept of reader satisfaction, analyze and study the changes of the needs of the readers, and combine with the library organization structure, literature products, service projects and reward and punishment measures for comprehensive consideration, making the reader's research as an important topic of modern university library management innovation, and making the reader satisfaction as the driving axis of the effective operation. It is necessary to carry out the reader's survey, and understand the 
reader's overall view of information services. Only taking the reader as the research object, taking the reader's satisfaction as the instruction, taking the technology as the means, and taking the knowledge information as the material foundation, the university library management innovation has the vitality to adapt to the development of knowledge economy era.

\subsection{Technological Innovation}

Technological innovation should fully support the knowledge expression and management, knowledge accumulation and delivery, knowledge mining and regeneration and knowledge utilization and evaluation, fully support the integration of services based on virtual resource system, and fully support the personalized, special and intelligent service. This technology system is a new type of knowledge management system, which combines the knowledge information resources with the user's application process, and has the functions of flexible invocation, integration, reorganization and reconstruction. This new technology structure and operation mode, to a large extent determines the efficiency and level of knowledge development services.

\subsection{Institutional Innovation}

In 1980s, foreign libraries began to implement the "Subject Librarian" system, that is, professional librarian system. At present, a small number of undergraduate colleges and universities in China has also implemented this "subject librarian" management system, which requires targeted collection and analysis of the literature information, taking the initiative to provide readers with multi-angle, deep-level, high level of service. This deep and initiative utilization on information has played a strong role in promoting the discipline construction, scientific research work, and the role of literature guarantee.

According to the job requirements of the "Subject Librarian" system, they should be the network administrator, information navigator suitable for the development of digital library, which requires "Subject Librarian" to build a higher quality so as to adapt to the need for networking, knowledge integration and discipline specialization. This has not only trained the team, cultivated the backbone, but also conducive to the library's innovation and sustainable development.

If the university library has become a real communicator, educator, organizer and navigator of professional information and resources in the school's key professional construction and teaching and research work, then this "Subject Librarian" system model is worth learning and promotion.

\subsection{Service Innovation}

Under the condition of knowledge economy, the readers of university library must change from the traditional service mode to the intelligent service mode, and develop the virtual reference service (VRD) creatively, the reader location service and short message service based on the digital library technology and network technology, and provide readers with timely, economical and practical innovation information on the basis of knowledge mining, integration and reorganization. Namely, to send the library to the reader's desk.

From the development trend of library service, the content of library service needs to be widened. Service should be flexible and diverse, which is an important measure to facilitate the reader, including the introduction of new books on the various subjects, so that the majority of teachers and students can be timely and relatively comprehensive understanding of the existing collection of the corresponding subject books.

\section{Strategic Analysis of the Core Competitiveness of Books}

\subsection{Mining Library'S Resources for Service Innovation}

The service work of library reader mainly takes the characteristic collection and the characteristic service as the core, breaks through the traditional service pattern, and carries on the service innovation. Then it comes out with the service which is different from the competitiveness, and peer cannot follow. Service innovation is not just shouting in the mouth, but the challenge of future service concept. In breaking the traditional concept of collection, it is also necessary to learn effective service methods from the various industries in a timely manner, to develop new and featured services. It can bring 
readers a sense of satisfaction, a sense of security and a sense of security whether in interest and in psychology. The implementation of special service is the basis for improving the core competitiveness of the library. Providing different services for different readers, such as providing reference services for enterprises, experts and policy makers, so that the competitiveness of the library is undoubtedly greatly enhanced. During the services, it mainly manifested as the strong competitive in the depth of the development and utilization of information. In the service mode, community service can be carried out, such as the clipping service, according to the demand of the individual active service; or to provide special services for enterprises to meet the needs of different users of entertainment, leisure, education and research needs. At the same time, strengthening the study is also necessary to anticipate the changes in the needs of readers, so that their service content is more advanced and times. For instance, according to the needs of teaching and scientific research, as well as the needs for information of the regional socio-economic development, the library of Huanghuai University set up the characteristic collection and built the Tianzhong Culture Database. According to the requirements of applied and compound talents training, and relaying on the national characteristic major - animation, the animation database with Huang Huai characteristics has been established. In order to gather the unique teaching and scientific research achievements of the school, the library has developed the "Huang Huai library". The above three databases have been linked to the library home page for readers to browse. They also have built an another library including foreign stacks, donated stacks, tool stacks, local literature stacks, to provide readers with more personalized reading space and resource selection.

\subsection{Brand Strategy}

Brand is the key to determine the outcome of the market competition. Creating a service brand should focus on the innovation and characteristics of the service, which is based on their own advantages and characteristics. With the deepening of the Internet, online navigation is an important content of the library. High-quality network service is an important part of the library brand, which gets rid of the constraints of time and space, reduces the link in information services, expands the scope of services, and improves service efficiency. In order to improve the core competitiveness, the library must provide high quality services, and establish the service brands. The concept of "user centered" is still the foundation of the library. While doing routine service, problem tracking service, novelty search service, special search service, Readers' satisfaction is still an important index to measure the quality of reader service. It is the starting point and the end result of the library that serve the readers and meet the needs of readers, then to create a service brand.

\subsection{Playing A Leading Edge Through Technological Innovation}

\subsubsection{Strengthening Technological Innovation and Expanding Service Projects}

In order to realize service innovation, technological innovation is the basis and means to improve the competitive advantage. With the application of advanced technology, information technology has brought great changes to the modern library from the aspects of service means, service mode, information processing objects and capabilities. In the information society, the multi-level needs of users require that the library must integrate with computer technology, network technology, multimedia technology, to improve the level of collection and ordering, development and utilization of information resources, especially the network information resources, so as to make the library work active, flexible, diverse and efficient. In the face of the complicated network information, through the classification of related disciplines of electronic journals, books, conferences and forums, bulletin boards, research institutions, the collected online information should be organized in order by providing the search window and database, so that readers can easily access the information on the internet, and make the information resources provided by the library more colorful, which is the concrete embodiment of technological innovation.

\subsubsection{Making Use of the Characteristics of Resources and Giving Full Play to the Competitive Advantage}

The library should choose the dominant direction according to its function. Resources should be focused on the development of key resources characteristics and the creation of special services. Such as the use of electronic information resources to create intelligent retrieval services (including the 
retrieval services for a variety of databases, dissertations database, research results database, experts and scholars database, etc). It is necessary to play the advantages of resources, strengthen research and development capabilities, develop independent intellectual property rights, and continue to carry out technological innovation. For example, the library of Huanghuai University has introduced the whole texts of CNKI, Doctoral and master's thesis database, VIP journals database, Superstar Digital Library, Springer-Link, Chinese Yearbook net and other databases; the establishment of the search platform of Huang Huai Chinese academic literature, which has integrated the Chinese e-book database, Chinese and English Periodicals Database, newspapers, papers, standards and patents and other various literature, realizing the one-stop retrieval of paper document resources and electronic document resources; Participating in the calis halis to improve the quality of service, making full use of $\mathrm{E}$ read, $\mathrm{E}$ line drawing and other shared resources to enhance the overall document information resources protection capabilities; Paying attention to the diversity of resources, which not only strengthen the introduction of scientific research database, improve the ability of teaching and research work, but also meet the requirements of the application of personnel training. The construction of relevant sources such as the cultivation of students' practical application ability, the improvement the students' testing ability and employment level are all included in the focus of the construction of resources. They have also brought the starting point of the examination network, Eddie Corson employment training database, New Oriental multimedia learning library, Helpdesk and other application database; strengthening the construction of the characteristics of the collection (Huang Huai animation library, Tianzhong Cultural Database, Huang Huai Library), and to realize the network management of optical disk data with the help of non-book publishing system. Digital resources have initially formed a complete system of scientific research reference, video teaching, and network self-learning, electronic reading.

\subsubsection{Creating Human Resources and Laying the Foundation for Quality Services}

(1) Cultivating a high level of talent team.

The core competence is highly dependent on talents. Competition in the library is the competition of talents. People are the key factors of the core competitiveness, and also the power source of library innovation. In the development of library cause, the role of talents is very important, and the problem of talents has become the key problem of the library's core competence. The arrival of knowledge economy era highlights the importance of talent, because talent determines the use of equipment, technology updates and the effectiveness of various management methods. Therefore, in the fierce market competition, it is necessary to build a high-quality talent team. The library leaders should pay more attention to the discovery and use of those with market consciousness, competition consciousness, innovation ability, management ability, public relations ability, analysis ability and sensitive to new things, so as to retain talent. To retain talent, a good environment is necessary to attract talent, through the introduction of high-level, high-level talent to enhance the library's core competitiveness.

(2) Building a learning organization

The formation of core competencies is the learning and accumulation of knowledge and technology. As a library accepting the challenge in the tide of the times, in order to build the library into a learning organization, it is necessary to fully tap the human resources, improve the quality of the key personnel, and make it a new type of talents with creative ability, continuously improve their scientific research and academic level, and gradually form a grass-roots staff training system. Encouraging staffs to supplement knowledge through self-study, short-term training and long-term full-time education, rapidly improving the overall quality of staff. Only the ability of learning and innovation which other libraries cannot imitate are obtained, can it adapt to the dynamic change of the external competitive environment and enhance the core competitiveness.

\subsection{Changing Management Model and Management Innovation}

As we all know, advanced management system is the premise to improve work efficiency and ensure the quality service. Adopting modern management mode, realizing management innovation is the powerful guarantee of giving full play to the core competence. Management innovation is a new 
mode of management thinking, its purpose is not to achieve the general management objectives and responsibilities, but to find opportunities for innovation, to bring potential benefits to the organization. In the knowledge economy era, a large amount of information and the increased information demand requires the library not only to have modern information processing technology and equipment, but also to meet the requirements management system. In the aspect of organization structure, the library should break through the "plate" management mode of the former function structure and subject structure. According to the needs of modern information network technology and business development, it is necessary to seek a new structure of inter-departmental cooperation. According to the actual situation of the libraries, practical management programs should be established and operated effectively. Under the planned economy, the library management mode is obsolete and must be updated. A management model should be based on their own characteristics, to form their own unique advantages. That is, how to develop information service and seek the development under the impact of market economy. For example, Huanghuai University library actively create a scholarly atmosphere, optimize the micro environment decoration, and strive to create a clean and elegant library, so that students accept the influence of cultural atmosphere imperceptibly; special reading room, foreign teacher training room, Doctor Salon, book house are all set up to provide the support of special resources and space resources for the cultivation of innovative ability of scientific research and applied talents; the salon for readers is set up to provide space for leisure discussion. So that the library can be transformed from simple "knowledge center" to "learning center". The library invites the well-known experts, scholars and social elites to give lectures, to enhance the knowledge content and cultural heritage. With the Reading Association as a bridge, the library actively carry out reading activities. World Readers Day, Reading Festival of Huanghuai University students are all carried out regularly, which can active campus culture, promote the campus humanistic spirit, and enhance the quality of students.

All in all, in the current competitive market environment, a library with lasting innovation ability and characteristic must be full of vigor and vitality, great energy and potential. The library should make unremitting efforts to maintain the core competitiveness, so as to promote the sustainable, stable and healthy development of the library cause.

\section{Acknowledgments}

Qian Zhang, female, (1965- ), Bachelor degree, Librarian.

Place of origin: Suiping County of Zhumadian City

Work unit: Library of Huanghuai University

\section{References}

[1]. Lang Li. On the current situation and Countermeasures of Public Libraries in China. Enterprise Science and Technology \& Development. 2006,09:46-47.

[2]. Shengmao Duan. Knowledge Management and Modern Library Development. Modern Information. 2006,08:55-57.

[3]. Ping Zhang. The Innovative Idea of University Library Construction. Journal of Zhengzhou University (Philosophy and Social Sciences Edition). 2006,03:168-170.

[4]. Nan Wang. Research on the Knowledge Management of University Library. Journal of Intelligence. 2007, 03:149-150+148.

[5]. Hongquan Liu. The Reform and Innovation of Library Management Organization. Modern Information. 2007,04:111-114.

[6]. Feng Hu. Knowledge Management, Competitive Advantages and Products Value. Journal of Intelligence. 2007, 02:2-3+6.

[7]. Hongmei Zhou, Chunmei Wang. Research on the Cultural Competitiveness of University Library. Information Science. 2012, 01:87-89+109. 
[8]. Mei Zhao. The Innovation of University Library Management in the Era of Knowledge Economy. Library Work in Colleges and Universities. 2004,05:26-28.

[9]. Chunhong Liu, Yanbin Shi, Wenli Zhong. The Modernization of University Library and the Quality Education of Librarians in the 21st Century. Library Work in Colleges and Universities. 2004,01:30-31.

[10]. Chenghua Zhang. On the innovation of university library to meet the challenge. Researches in Library Science. 2002,03:99-100. 